\title{
Secondary Education in Uganda: Resource Mobilization and Efficiency
}

\author{
Godwin Tindyebwa Muhangi \\ Mbarara University of Science and Technology, P. O. Box 1410 Mbarara, Uganda
}

\begin{abstract}
Over the years, scholars and researchers alike have evaluated the basic components of quality secondary education. This has been the case in Uganda and other countries. Success on such an undertaking requires that countries will have to confront the resource requirements for maintaining growth and expansion trends in secondary education. Uganda as a developing country is faced with limited educational resources and a concerted effort from all stake holders must be put in place to mobilize the required resources to improve efficiency of this sector. Such would allow schools operate with minimum difficulty and realise the objectives of secondary education. Adequate resources have been not mobilized to allow secondary schools in Uganda fully realize governments' existing plans for secondary education. The limited available resources are competed for with other demands in the public sector; making it difficult for the government to mobilize additional resources to make secondary education efficient. Additionally, challenges related to increased access to education, financing, increased refuge population, teacher supply and resource allocation all limit efficiency of secondary schools in Uganda. Also, the secondary education curriculum has been said to be outdated, irrelevant, or poorly implemented and this reduces efficiency of secondary education. Without practical steps to improve efficiency in terms of quality and relevance, secondary education is likely to consume vast amounts of resources without leading to the hoped benefits of improved social and economic development. This paper illumines secondary school resources in Uganda, how such have been put to use and how this has not realised the desired levels of efficiency. This could be attributed to unsatisfactory resource mobilization strategies. The stakeholders need to step up their resource mobilization strategies. Alternative sources of funding such as engaging in income generating activities will provide desired finances and certainly improve the efficiency of the sector.
\end{abstract}

Keywords: Secondary, education, Resource, mobilization, efficiency

DOI: $10.7176 / \mathrm{JEP} / 10-20-10$

Publication date:July $31^{\text {st }} 2019$

\section{Introduction}

Uganda recognizes and upholds the right to education as indicated by various policy documents (Right to Education Project, 2012). As a nation, Uganda appreciates education as a "tool" for national stability and development (UNESCO, 2014) and an agent for nation building and social cohesion (Zebun, 2016). While issues associated to primary and higher education have been diagnosed for long; secondary education and its peculiar attributes are still scanty in the education literature (Jacob \& Lehner, 2012). It is important to critique issues surrounding secondary education in Uganda. According to Chapman, Burton and Werner (2010) for example, wider access to good secondary education is a critical element for the achievement of the goals of human development, political stability, and economic competitiveness. This can only be possible with enough resources for efficient operations within the sector.

Secondary education as an intermediary level between primary and higher education prepares the youth for the world of work and equips a largely adolescent population with the skills, aptitudes, and social values for a productive and healthy adult life (Jacob \& Lehner, 2012). It is therefore fundamental that resources for secondary education be mobilized to allow schools take care of the educational needs of such youths. It has thus been suggested that a well-planned and adequately resourced secondary education has potentials for equipping students with skills and knowledge required for better economic and social participation in a peaceful, democratic society. Also, secondary education contributes towards the development of the knowledge necessary to avoid risky behavior for better and healthy lives (UNESCO, 2010).

While the above depicts the desired goals for secondary education, such have not been fully achieved (Sentongo, 2018). This has been attributed to insufficient resources in terms of finances, teachers or technical support to the secondary education sector (Chapman, Burton \& Werner, 2010). Many factors relating to secondary education resources have limited the achievement of secondary education goals. For example, a shortage of schools, as well as the inability to pay for education, have limited achievement of secondary education goals such that the quality of secondary in Uganda often is poor (Uganda Government, 2018). Achieving the goals of secondary education requires increasing resource supply including scholastic materials, teachers, finances and infrastructure (Obadara \& Alaka, 2010).

Several challenges limit the achievement of secondary education in Uganad. These challenges are largely related to resource mobilization. If this is not achieved, the challenge will become insurmountable making the 
goals of secondary education unachievable. Issues of financing, curriculum, and access together with their consequent effects on efficiency in secondary schools have been cited but these have not been well knitted together in the context of Uganda. Additionally, mobilization of funds and other resources for secondary schools in Ugandan is something that requires analysis. This paper makes suggestions on how Uganda can address the multiple challenges related to resource mobilization faced in secondary education and then grow the sector efficiently.

\subsection{The secondary education context in Uganda}

There is a great international heterogeneity regarding secondary education provision, its content, length, and the age cohort engaged in it (OECD, 2018). Consequently, while many people have an idea of what secondary education is or what it should be, there exist differences in national interpretations of secondary education (Jacob \& Lehner, 2012). Many countries define secondary education differently (Eubanks \& Eubanks, 2011). In the Ugandan context, secondary education is a six year cycle from senior one to senior six having learners with average age between 14 years and 19 years (National Curriculum Development Centre, 2018). It is one of the different options for educational progress within Uganda's education system (Uganda National Commission for UNESCO, 2010).

The secondary cycle of education in Uganda lasts for six normal progress years including four years ordinary secondary level (lower secondary) and two for Advanced secondary level (higher secondary) (JICA \& IDCJ, 2012). On successful completion of the ordinary level of secondary education, students are awarded the Uganda Certificate of Education i.e. UCE (Nuffic, 2016). Successful senior four leavers have four possible paths through which they can attain further education: they can either proceed to advanced level of education; join two-year advanced crafts courses in technical institutes; join a two-year grade III primary teaching programme; or join any of the government's departmental programmes such as agriculture, health, veterinary, and cooperatives (Uganda Investment Authority, 2010). On successful completion of upper secondary, students are awarded Uganda Advanced Certificate of Education (UACE) (Uganda Government, 2012). Successful upper secondary school leavers proceed to university or join a two-year courses leading to ordinary diploma in teacher education, technical education; business studies or join departmental programmes (Uganda Investment Authority, 2010).

\subsection{Provision of secondary education in Uganda}

Secondary education occurs in distinct secondary schools whose ownership is variable. According to Uganda Bureau of Statistics (2017), provision of secondary education is through a three types of secondary schools i.e. government, private sector and community owned secondary schools. Secondary schools owned by the government may either be government aided schools or grant aided schools previously community owned but have been taken over by government (Education Act, 2008). On the other hand, private secondary schools are founded and owned by private individuals, religious bodies or NGOs and they currently constitute $66 \%$ of all secondary schools in Uganda (Kazuya \& Chikako, 2016). International schools that deliver foreign curricula also exist though they are only a few of them (Sentongo, 2018).

Irrespective of their ownership, secondary schools are managed and supervised by Ministry of Education and Sports (MoES) whose mission is to provide, support, guide, coordinate, regulate, and promote quality education and sports for national integration, individual and national development of Uganda (MoES, 2013). Thus, secondary education in Uganda is provided by both the government and the private sector (Education Statistical Abstract, 2016). Some private schools receive some funding from the government (hence called government grant-aided schools) under the Public Private Partnership (PPP) (Namusobya, Aubry \& McKernan, 2015). Also, the Ministry of Education ensures that trained teachers are deployed; salaries and allowances are paid to teachers; educational materials and other capital development inputs provided; national selection. Besides admission guidelines are followed for all students enrolled in both government and government-aided schools (Makaaru, Cunningham, Kisaame, Nansozi \& Bogere, 2015). In private secondary schools, the government mainly ensures that private schools conform to rules and regulations governing provision of education services (Huylebroeck \& Kristof, 2015). The government is also responsible for deployment of teachers and head teachers, placing students and organizing national examinations.

The Government of Uganda introduced Universal Secondary Education (USE) in 2007 to increase access to secondary education for economically vulnerable families and communities (MoES, 2013). This is carried out in some government and private schools termed as USE and PPP Schools (Bo-Jo, 2011). In such schools, students are automatically promoted but to proceed from O-level to A-level and graduating from A' level, one needs to pass national exams administered by the Uganda National Examination Board or UNEB (Huylebroeck \& Kristof, 2015).

The available literature on secondary education does not provide insights into efficiency and resource mobilization in secondary schools in Uganda. Much of the literature for example focuses on the impact of USE 
on secondary school enrolments (Kazuya \& Chikako, 2016), the impact of USE on teachers and moonlighting activities and the importance of involving head teachers in policies such as USE (Chapman, Burton, Werner, 2010). Other studies have investigated incidences of poor service delivery in secondary schools (Urwick \& Kisa, 2013) characterised by higher teacher absenteeism (Molyneaux, 2011). There have been no attempts to diagnose efficiency and resource mobilization in secondary schools in Uganda. This paper provides an insight on mobilization and resource efficiency in secondary education in Uganda; and serves as a catalyst for studies in this area.

As suggested in this paper, variation in the nature of secondary schools in Uganda has implications for efficiency and resource mobilization strategies for such schools. According to the Education Statistical Abstract (2016), there are about 3,070 secondary schools in Uganda including 1,058 government secondary schools and 2012 private secondary schools. 690 of the private secondary school are under public private partnership and thus receive funding from the government together with 902 USE school. 372 secondary schools (12\%) are registered while $497(16 \%)$ are licensed and 2,201 secondary schools (72\%) are registered. It is argued in this paper, that the different secondary school types have different sources of resources. The different sources influence the resource mobilization strategy and certainly impact the efficiency. In a country with one of the worlds' highest youthful populations (Uganda Bureau of Statistics and ICF, 2017), a variety of educational providers, and an influx of refugees, there is need for a critical consideration of resource provision to the secondary education sector in Uganda for purposes of improving efficiency (Uganda National Commission for UNESCO, 2010).

\subsection{Role of secondary education in Uganda}

Development of human capital through education significantly contributes towards national economic growth, development and improvement in well-being among citizens (Anikina, Ivankina, Tumanova, 2015). In recognition of this, there has been intense policy discussion about education, society and national development (African Network Campaign on Education for All, 2012). Concomitantly, secondary education has become a policy concern of developing countries, particularly among those that have progress in terms of universal primary education (UPE), and those in which demographic transition has shifted towards adolescents (Uganda technology and Management University (2016). This is well represented in academic literature and is reflected in political debates for developed and developing countries (Kulid, 2014). This makes reference to Uganda; a developing country that has progressed in terms of UPE provision.

Secondary education being intermediate between primary and higher education plays specific roles (Damon, Glewwe, Wisniewski \& Sun, 2016). Because of the different education policy issues that have been associated with education in Uganda, the context has been changing over time (Uganda National Commission for UNESCO, 2010). This has significantly influenced the roles of secondary education. Policy makers in Uganda have had a thorough consideration of these roles. According to the Curriculum Development Centre (2018), the roles of secondary education in Uganda include the following:

- Secondary education instills and promotes national unity and an understanding of social and civic responsibilities; love and care for others and respect for public property, as well as an appreciation of international relations and beneficial international co-operation.

- It promotes appreciation and understanding of the Uganda cultural heritage and its languages.

- Through secondary education, sense of self-discipline, ethical and spiritual values, personal and collective responsibility and imitativeness are imparted and promoted.

- Secondary education enables students to acquire, develop and appreciate emerging societal and economic needs.

- It provides updated and comprehensive knowledge in theoretical and practical aspects of innovation, modern management methods in commerce and industry and their application in socio-economic development.

- It allows development of basic scientific, technological, technical, agricultural and commercial skills required for self-employment.

- It enables development of personal skills in problem-solving, information gathering and interpretation, independent reading and writing and physical or social self-improvement.

- It provides a foundation for further education.

- Allows individuals to apply acquired skills in solving problems of the community and to develop a strong sense of constructive and beneficial belonging to that community.

- Instills positive attitudes towards productive work and strong respect for the dignity of labour and those who engage in productive labour activities. 


\section{Resource mobilization for secondary education in Uganda}

The 2012 Rio de Janeiro United Nations Conference gave rise to Sustainable Development Goals (SDGs). These are universal goals to meet world environmental, political and economic challenges (United Nations, 2012) that replaced the Millennium Development Goals (MDGs). MDGs set a platform for human development and expanded primary education to all children, among other development priorities (United Nations, 2017). Also, MDGs facilitated growth, reduced poverty, improved access to water and sanitation; reduced child mortality and improved maternal health (United Nations, 2015). Most importantly, MDGs led to the adoption of UPE which increased the number of candidates for secondary education and certainly presented quality related challenges (Jacob \& Lehner, 2012).

Secondary education needs in Uganda have been on an increase due to the introduction of UPE in 1997(Asankha \& Takashi, 2014). However, it is also recognised that quality secondary education generates opportunities and benefits for social and economic development as envisaged by the SDGs (Patrinos, 2016). This notwithstanding, secondary enrolment grew from 954,000 in 2007 to 1.5 million by 2016 (World Bank, 2018). This challenges provision of quality secondary education and requires more resources towards secondary education (Ministry of Finance, Planning and Economic Development, 2018). Considering the SDGs, goal No. 4 emphasizes the need for 'quality education' by ensuring that education is inclusive and promotes lifelong learning (United Nations, 2012). For this goal to be achieved, governments and donors need to commit resources to mitigate factors that limit attainment of quality education.

Secondary education resources are obtainable from the government, parents and donors (Baghdady \& Zaki, 2019). Thus, depending on the nature of the school, resources are mobilized from any or a combination of the mentioned sources. In government non USE secondary schools, government funds are used to pay salaries - a fraction of the total expenses on secondary education (Sentongo, 2018). Consequently, secondary education in non-government aided secondary schools relies on resource mobilization from sources such as households mainly through user charges (Omoeva \& Gale, 2016). Thus, schools should initiate alternative sources of income and try to make up for the budgetary deficits. This requires a thorough consideration of the alternative funding mechanisms, the budgeting process, expenditure items, and the design of the fiscal system (Gongera \& Okoth, 2013). Funding sources themselves influence education efficiency and quality (Gogo, 2012). This paper discusses different funding sources with the basic argument that Uganda should consider rearranging or reforming the financing mechanisms so as to ensure sustainable resource mobilization and efficiency of secondary schools.

Better resource mobilization for secondary schools in Uganda entails expanding public funding, encouraging contributions from the private sector, or the international community (UNESCO-UIS, 2011) besides encouraging income generating activities at school(Omukoba, Simatwa \& Ayodo, 2011). Additionally, financing programs need to mix different funding sources in innovative ways (Education Task Force of innovative financing to fund development leading group (2012). Without such engagements, the quality of secondary education will be unattainable and certainly bring about inefficiency.

\subsection{Sources of funds for secondary education in Uganda}

According to World Bank (2018b), Uganda is on track towards the achievement of universal primary education (UPE). This requires Uganda to determine strategies and financing options for the expanded secondary education that are consistent with national human capital development goals. This is because fiscal constraints cannot allow the country to solely rely on government financing for the expanded secondary education (Glennerster, Kremer, Mbiti \& Takvarasha, 2011). With the eminent difficulties, adoption of policies to reduce the burden of secondary education funding has been inevitable. The strategies include (1) charging tuition fees as a contribution towards the cost of public secondary education; and/or (2) privatization policies to encourage development of private schools and shoulder part of surging numbers (UNESCO-IIEP, Pole de Dakar, UNESCO-UIS, 2016a). This informed four sources of funding to secondary education in Uganda and these are the state, households, local communities (including donations from), and Multinational development partners (Gongera \& Okoth, 2013).

2.1.1. The state (Public sector)

Uganda government has the responsibility for education provision; it plays a central role in ensuring efficient, equitable and effective management and financing of public education (Makaaru, et al; 2015). This depends on the school status: whether government aided or not; for example out of the 3,149 secondary schools in Uganda, only $39.4 \%$ are government funded (MoES, 2016). By being government aided (including government non USE, USE and PPP), schools receive funding from the government as a proportion of the national GDP. In 2013, government expenditure on secondary education was reported to be $0.6426 \%$ of GDP of Uganda (Trading economics, 2013) and this is a very low value which certainly limits efficiency the sector. National governments worldwide spend copious amounts of public resources to fund education services, yet access to those services is not always equitable for all intended beneficiaries (Mugendawala, 2012). This limits efficiency since not all the intended users access it (OECD, 2012). Access to secondary education is skewed towards specific segments such 
as educated classes, schools, regions and wealth quantiles; only those with access to public schools benefit from public education resources (UNESCO-IIEP, et al; 2016a).

In attempt to improve access and efficiency in Ugandan secondary education, the government introduced USE programme (Bo-Joe, 2011). Through this programme, the government offers eligible students free places in some government aided secondary schools (Asankha \& Takashi, 2012). The government aided schools were supplemented by some private schools through the PPP since there was a limited number of government aided secondary schools when the programme was introduced (Bo-Joe, 2011). Like the government aided schools, PPP schools receive specific support from the government including the provision of textbooks and other teaching. While the introduction of USE is appreciated for it solved some challenges related to access secondary education, the programme has been said to be inefficient (Huylebroeck \& Kristof, 2015). It is thus imperative that the government revisits the USE policy so as to marry efficiency with the purposes of USE.

2.1.2 Households

This relates to the funds paid by families for their children to attain secondary education. Such expenses relate to tuition fees paid directly to the school and other school related payments made both inside and outside of schools, such as catering costs, transportation costs, uniforms, and textbooks (Ministry of Education \& Sports, 2013). It has been reported that households fund more than one-half of education expenditure in Uganda (UNESCO-IIEP, et al; 2016a). For private secondary education however, households are the main sources of funding. Additionally, households fund a considerable portion of secondary education spending in government funded schools. Such spending may be formal or informal; direct or indirect contributions from households (Omoeva \& Gale, 2016).

For private secondary schools, fees and other charges payable to schools constitute the most significant items paid for by the students' household (Smith \& Baker, 2017). In addition to such payments, households pay for other charges such as registration and examination fees, auxiliary fees, contributions to parent-teacher associations or school management committee fees (World Bank, 2018b).In Uganda, other payments represent $38 \%$ of household expenditure on education in public schools but when taken together, payments made outside of schools for items such as uniforms, teaching materials, private classes and other expenses represent more than half of what households spend on education, especially in public schools (UNESCO-IIEP, 2016a). It has also been reported that households fund at least $50 \%$ of the cost of teaching materials in Uganda (ibid).This represents a heavy burden of students' secondary education costs borne by households. If not considered carefully, they exclude some students from secondary education.

From the above, it is shown that household contributions constitute an important source of secondary education financing and, with good policy design; they could provide sustainable subsidies for the poor and help improve efficiency and accountability by increasing the schools' responsibility to parents (Crawfurd, 2016). Furthermore, household contributions can increase reliability and resilience of institutional service delivery and thus help to ensure that the education provided meets the demand (Zheng \& Libertus, 2018). However, excessive reliance on household contributions can depress enrollments, even when there is excess capacity (Alecke, Burgard, Mitze, 2013). User charges and fees have a substantial impact on parents' decisions about their children's schooling (Kiage, Simatwa \& Ayodo, 2014). The government should come in to regulate fees charged especially in private secondary schools.

As already indicated, teaching materials are largely funded by households and this affects the quality of learning; poorer households experience greater difficulty because they are expected to fund teaching materials (UNESCO-IIEP, 2016a). Children from poorer households have less access to adequate materials, which may hamper their learning. Thus, when the burden on households to pay for their education is too heavy, issues of equity and accessibility may arise (OECD, 2018). This is an area that policy makers need to consider critically. 2.1.3 Funding from multinational development partners

Multinational development partners play a small but significant role towards secondary education funding to a tune of about $7 \%$ of total secondary education funding (UNESCO-IIEP, 2016a). They include the European Union, the World Bank, African Development Bank, and Master Card Foundation among others (UNECO, 2014). Their funds come in through the government either as loan or grants (UNESCO-IIEP, 2016a). For effective policy formulation and analysis, it is important to identify whether the support is given as a loan or grant (MoES, 2017). Loans have to be reimbursed and could be understood as part of national government funding yet this has long term impact on national economy. Grants on the other hand are sources of external funding and contribute towards educational development with no 'strings attached' (Gabriela, 2013).

An Education Funding Agency Group (EFAG) has been established to bring together all donors that provide financial and technical support to the education sector to improve coordination among these donors (Sentongo, 2018). While this is done, Uganda needs to evaluate the impact of educational loans from development partners on education. Continuous borrowing without evaluation of the impact may not support the goal of attaining middle income status in the near future. The country could certainly do better by generating revenues locally to finance her secondary education. 


\subsubsection{Donor funds from NGOs and religious bodies or individuals}

Secondary education to particular students in Uganda is funded through donor funds generated from local NGOs and religious bodies or even philanthropic individuals (Hedger, Williamson, Muzoora \& Stroh, 2010). Some faith-based organizations (FBOs) are important actors in either managing or financing (or both) secondary education activities (Ministry of gender labour and social development, 2011). Others have fully or partially been financing students' secondary education (Uganda secondary education improvement project, 2018). Also, community-based organizations (CBOs) which are non-profit entities working at a local level to improve the lives of residents in social fields and have often been involved in providing and/or funding educational services at local level (Ministry of gender labour and social development, 2011).

These entities fund secondary education through school fees payment and /or other charges especially in form of scholarships or bursaries (Alcott, Rose \& Sabates, 2016). In some cases, the educational support is in form of cash transfers to students or their families who then use the funds to pay for tuition and/ or other education expenses (Gordon \& Rose, 2018). While the end education service is attained by students, the source of the funding is the donor agency. In some other cases, the scholarship is transferred through the school (the producing unit) before reaching the student (UNESCO-IIEP et al; 2016a).

Thus, the local community (such as local NGO and the church) fund secondary education by supporting poor students or their household to enable students who would have otherwise not been able, access secondary education. This is an avenue that can further be developed especially with the government coming in to support more learners to access education. The government can for example commit funds in form of scholarship directed to schools which can in turn use the funds to exempt, partially or totally, the targeted students from payment of tuition or user fees (UNESCO-IIEP et al; 2016a). A similar case would be a government subsidizing students attending private schools by channeling its support directly through the student with a scholarship (Sentongo, 2019). Alternatively, the government could give the institution a specific amount for each student it subsidizes. In all cases, access and efficient operation of secondary education can be achieved.

\subsection{Efficiency of secondary education in Uganda}

Efficiency of a sector depends on the extent and nature of funding extended to the sector in consideration (Nunnenkamp \& Öhler, 2010). With this in consideration, public spending for education in Uganda, as a share of GDP compared with countries with similar GDP per capita, is well below expectations for secondary education (World Bank, 2018b).This effects efficiency of the secondary education sector. National spending as a share of the national budget on secondary education has been on a decrease i.e. from $15 \%$ to $11 \%$ over the last few years despite the introduction of the Universal Secondary Education (USE) policy in 2007 (Bashir, Lockheed, Ninan Dulvy, Tan, 2017). Due to the decrease in public funding to the sector, the burden of financing has been shifting to households in both public and non-government schools (World Bank, 2018b). Since the economic muscle of some households is weak, some students miss a chance of attaining education. Thus, the government needs to step in and iron out this anomaly.

Access to secondary education in Uganda has been on the increase largely due to the existence of private secondary schools and presence of the USE programme (World Bank, 2018b). This has however not been experienced in the world of work; the average level of education of the work force remains low and does not meet labor market requirements (World Bank, 2018a). This notwithstanding estimates from the National Household Survey (2016) show that only entrants with postsecondary education can escape informal sector work. This can be attributed to an inefficient secondary education sector. Thus, to increase employability and productivity of the expanding workforce, supply of quality education, especially for low-income, rural households and girls, is critical. Only one in five people (20\%) aged 15 and above have completed secondary education (National Household Survey, 2016). This has led to a large number of youth entering the job market without foundational skills of basic literacy and numeracy, as well as generic skills essential for life and work (World Bank, 2018a).

The above shows that Uganda faces a challenge of expanding secondary school enrolment (Bashir, Lockheed, Ninan Dulvy \& Tan, 2017).Though enrollments in secondary education have increased since the introduction of USE at an average rate of $6 \%$ per year, growing from a total of 954,000 students enrolled in 2007 to over 1.5 million in 2016, the pace of increase in enrollment remains low in comparison to Uganda's neighbors (Bashir, et al; 2018). Such an increase is attributed to the many private secondary schools in the country which stand at about $59 \%$ of secondary schools enrolling slightly above half of enrollment (World Development, 2018). This has nevertheless not improved the secondary enrollment rate which is significantly below that of regional comparators (World Bank, 2018b). In 2016 the average annual enrollment increase stood at $25 \%$ in Kenya and $16 \%$ in Rwanda (World Development Report, 2018). Furthermore, Gross Enrollment Rates (GER) have stagnated since 2007 with GER at only $28 \%$ in 2017, much below enrollment rates in neighboring countries. GER in Kenya, Rwanda and Ethiopia was 58\% (in 2009), 37\% (in 2016) and $38 \%$ (in 2012) respectively (UNESCO Institute of Statistics, 2018). Very low enrollment rates in secondary education and the lack of 
progress indicate inefficiency of the system.

There is also notable enrollment disparity between boys and girls all over Uganda with the disparity being skewed positively towards boys (Education and Sports Sector Annual Performance Report, 2016). Great disparities are in urban centers of Soroti, Mbale and Kampala which all have high GERs of 47, 60 and $53 \%$ respectively (ibid). The high GERs have not even improved Gender Parity Indices (GPIs) implying that a high GER is not indicative of a high GPI. This suggests that increasing supply itself does not necessarily address gender imbalance in schools. Efforts to address the challenge of gender imbalance in secondary schools should be devised.

The combination of issues discussed above leads to an overall low performance of the education system including poor learning outcomes and thus an inefficient secondary education sector. This has resulted in a declining trend of student learning especially science subjects and math (Education and Sports Sector Annual Performance Report, 2016). Additionally, there are differentials across gender especially in sciences and math and across urban and rural schools (ibid). The persistent decline in performance points to an urgent need to address the quality of secondary education. An analysis of UCE results in 2015 and in 2016 showed that over $52 \%$ and $58 \%$ respectively, of the candidates failed to pass in at least division 3 and therefore have marginal prospects for further education and employment (World Bank, 2018b). Students perform worst in science subjects with approximately half of those who sit not passing mathematics, physics, chemistry and biology (ibid). Similar experience is observed at advanced level though performance in UACE examinations is only slightly better given that only the best performing O-level students proceed to A-level. This weakens the foundation for further learning besides undermining the country's potential to tackle poverty.

\subsection{Restraints to efficiency in secondary education in Uganda}

Section 3.0 is an overview of efficiency related issues in secondary schools in Uganda. Insufficient resources coupled with improper allocation attracts inefficiencies in the sector and consequently undermines performance and productivity of the entire sector. While inefficiency is the observed factor, several other challenges augment the status quo which inter alia includes: poorly distributed and few secondary schools in the country which limit efficiency of the sector (Statistical Abstract, 2016). This reduces the capacity to address the existing and growing demand of secondary education resulting from high population growth rate, the rise in primary school completion, and the recent influx of refugees.

Low survival rate throughout the education cycles also limits internal efficiency (World Bank, 2019). In 2017 , primary school survival rate was $56 \%$, which is considerably below the primary survival rate in Kenya, which is close to $100 \%$, Ethiopia at $72 \%$, or Rwanda at $68 \%$ (World Bank, 2018b). This implies that it takes almost twice as many years of schooling than normal to 'produce' a graduate in primary and secondary education. The inefficiencies persist through secondary school, largely as a consequence of low transition rates to lower secondary (Sentongo, 2018). This increases the cost of education such that, the cost of service provision at the secondary level in 2013 was 2.3 times higher than what it should have been (Wodon, 2016).

Improper use of resources characterised by inefficient deployment of teachers across secondary schools also limits efficiency and this has resulted in several schools ending up with too many or too few teachers (UNESCO 2014). It has been reported that $40 \%$ of teachers in secondary schools in Uganda are placed in schools based on factors other than the class time required by students (ibid). This has been attributed to an outdated curriculum which further complicates teacher allocation across schools by imposing too many subjects that require specialized teachers (Uganda technology and Management University (2016).

The influx of refugees into Uganda further exacerbates inefficiency especially in terms of access (Uganda CPF, 2016). Uganda is Africa's largest refugee hosting country and one of the five largest refugee hosting countries in the world (UNESCO-IIEP, et al, 2016a). According to the UN High Commission for Refugees (UNHCR), Uganda hosts over 1.4 million refugees. Since refugees share all social services with host communities, the refugee population strains the already limited resources, including education (UNHCR, 2019). Majority of the refugees are hosted in the Northern districts of Uganda yet these are the least developed in the country with much lower levels of human capital and enrollment in education (World Bank, 2018b).

Refugees currently make up over half of the total populations in some districts and in the 12 refugee hosting districts, the secondary school-aged population (13-17 years of age) including both refugee and host communities is estimated at 310,121 (with the refugee population estimated at 147,020 and the host community at163,192) (Education Response Plan for Refugees and Host Communities in Uganda 2018). Secondary school provision is limited for refugees and host communities in the refugee hosting districts and this limits efficiency-an issue that should be looked into. Only $11 \%$ of refugees in eight of the refugee hosting districts have accessed secondary education, with only $33 \%$ of these being girls (Education Response Plan for Refugees and Host Communities in Uganda 2018). In the same twelve districts, only $18 \%$ of the host community secondary school aged children are enrolled, which is considerably below the national average (ibid). These additional pressures further exacerbate the crisis-like situation. 
Worth noting also is that girls' experience of secondary education is characterized by lower access, high dropout and low transition rates compared to boys (Jones, 2011). In 2016 the enrollment rate for boys was $29 \%$ compared to $25 \%$ for girls (i.e. $4 \%$ lower than that for boys) and the GPI was $86 \%$. In the same year, completion rates at ordinary level for boys were $40 \%$, compared to $36 \%$ for girls. Such disparities widened at the transition point to Senior 5 such that $34 \%$ of boys and $24 \%$ of girls transitioned to the next level (Education and Sports Sector Annual Performance Report, 2016). Also, learning outcomes tend to be lower for girls in certain subjects. For instance, in 2016 only $33 \%$ of girls in Senior 2 were proficient in mathematics in comparison with $49 \%$ of boys (ibid). Thus, a lot needs to be done to bring about efficiency.

According to Ahikire \& Madanda (2011), the main reasons for girls dropping out of secondary school are pregnancy (40\%), marriage (28\%) and the high cost for secondary education (7.3\%). Uganda's levels of child marriage are above expectations (Walakira, Muhangi, Munyuwiny, Matovu, Awich, 2016) leading many women (36.5\%) that marry before 18 years (Demographic and Health Survey, 2011). The probability of completing secondary education for woman aged 25-34 who married after 18 is 12.9 points higher than for women who married earlier (World Bank, 2018b). This suggests that continued schooling delays marriage and appropriate policies should be implemented by schools to prevent early marriage and pregnancy. Related to the preceding, distance to lower secondary schools for young adolescents, especially girls from poor families tends to raise opportunity costs and physical risks (ibid).

Despite the relative importance of the PPP arrangement, there are several challenges in its design and implementation which undermine its potential effectiveness (Matsiko, 2017). There is lack of accountability to government and poor learning outcomes in some private schools (Barrera-Osorio, de Galbert, Habyarimana \& Sabarwal, 2015). In addition, private provision tends to focus on densely populated areas with strong demand, often ignoring the poorest and most underserved parts of Uganda (Day Ashley, Mcloughlin, Aslam, et al; 2014). It is for this reason that policy makers have been advocating to end the PPP arrangement and shift its funding to the construction of new government secondary schools though this choice of action is potentially detrimental to the system (Barungi, 2017).

Inefficiency can also be attributed to low levels of access and equity that have been exacerbated by an outdated curriculum and low quality teachers (Uganda secondary education improvement project, 2018). The secondary education curriculum has been under revision with the aim of improving the quality and relevance of education and training leading to better learning outcomes. The curriculum is 'overloaded' with too many subjects and does not fully meet labor market competencies (Nsubuga \& Okwakol, 2014). This should be reformed to reduce the number of subjects and refocus pedagogy making it more student-centered and competency-based in order to produce graduates with skills relevant to the changing labor market (World Bank, 2018a).

A low quality teaching force, often lacking the necessary skills, leads to poor learning outcomes hence an efficient education sector (Ministry of Education \& Sports, 2013). The current teacher policies are inefficient in terms of attracting talent, supporting strong head teachers, and providing support to teachers to improve instruction (World Bank, 2018b). There is also a lack of subject proficiency and all these impact on student learning. Though $90 \%$ of secondary school teachers in Uganda have the required formal qualifications, research has shown that secondary teachers do not have the content knowledge and also lack sufficient pedagogical skills to teach (UNESCO, 2014). For example, only $66 \%, 70 \%$ and $17 \%$ of teachers are proficient in English, mathematics and biology respectively. This has a great impact on the efficiency of secondary education.

\subsection{Improving efficiency of secondary education in Uganda}

It is no doubt that the private sector plays a significant role in increasing access to secondary education in Uganda (Namusobya, Aubry \& McKernan, 2015). Most secondary schools in Uganda are private schools and provide education to the majority of students enrolled in secondary education (ibid). There are 1.6 million students in secondary education, out of which $41 \%$ are in government managed schools and $59 \%$ in independently-managed schools. It is therefore worthwhile for government to step in to support private secondary schools to allow them overcome efficiency bottlenecks.

To further improve efficiency, secondary education should adopt new funding sources to generate additional revenues. Additional incomes from alternative sources make school management easier (Gongera, \& Okoth, 2013), enable schools to pay workers on time and even hire extra labor whenever it was required (Omukoba, Simatwa, \& Ayodo, 2011). The extra funds can also be used to hire more teachers, take students for benchmarking and motivate the students and staff and infrastructure improvement (Gogo, 2012).

Secondary schools should also be more grounded in their immediate communities so as to improve their efficiency. The relationship between the school and immediate community should be strengthened to facilitate community participation in school activities (Sa'ad \& Sadiq, 2014). The parent- teacher associations should be made more active, school management committees formed and, in certain instances, local-based committees created. These interventions are instrumental in making community participation an effective channel: providing 
a legal framework for local participation, creating structures for participation and training and orientation programmes to developing local capacity (Bakwai, 2013).

There is a need to move from a control-based and visitor oriented inspection system to a mechanism that provides innovative supervision and support to schools where needed (Directorate Education Standards, 2014). The idea that supervisors need to be more involved with teacher training and demonstration classes, to assist schools to evolve development plans etc. is important. A substantial part of what is now the job of the supervisor can be replaced by strengthening internal management of schools, i.e. internal and local monitoring systems. Unfortunately, developing countries like Uganda invest too little in supervision activities to make them effective which limit the attainment of the desired end.

\section{The final thoughts}

\subsection{Conclusions}

The paper examined alternative sources of financing as a precursor to resource mobilization in secondary education in Uganda and how this has influenced the observed efficiency of secondary education in Uganda. The following conclusions are worth noting;

In addition to secondary school government funding, household sponsorship, and donors that may be local or international were also identified. These sources are however insufficient regarding to the current needs of the existing secondary sector. The funding modes have failed to improve gender disparity and a greater burden is currently being borne by households. This has consequently affected the efficiency of the secondary schools especially with regard to meeting the development needs of the country. Secondary school graduates are of poor quality because the secondary education sector is inefficient. Resource mobilization should be addressed so as to improve secondary education efficiency.

\subsection{Recommendations}

In addition to the existing funding sources, secondary schools should explore other alternative sources (income generating projects) that may be agricultural based, commercial based or service based. Agricultural based income generating projects include livestock and crop farming. Commercial based activities may include school canteen, confectionery shop and bakery. Service based income generating activities may include school bus hire, hire of furniture and school fields, school halls and equipment. Other than income generating projects, other funding options may include government bursaries, and Fundraising activities.

It is also recommended that there should be interventions aimed at increasing access to secondary schools and reducing cost of education for poor households and providing incentives for girls to stay in school. Such will positively affect education access and attainment. The government through the Ministry of education should formulate policies that will enable schools to have alternative sources of financing secondary education to break the overdependence on free day secondary funding that does not seem to be sustainable from the findings of the study.

The government through the ministry of education should develop structures within secondary schools and also promote in-service training courses to train school managers on effective management of projects. This will allow schools to generate funds internally and hence be able to subsidize the fees charged and therefore affordable to most households. This will increase access, improve retention by preventing drop-out and facilitate achievement of SDG no. 4.

The secondary school curriculum should be revised to give more emphasis to subjects that encourage development of both cognitive and psychomotor skills. This will lead to realization of quality education for selfreliance, in line with the national goals of secondary education. Additionally, teacher re-training and continuous professional development of all teachers should be initiated and maintained to refresh teachers with desirable skills, knowledge and attitudes for the realisation of goals of secondary education.

\section{References}

African Network Campaign on Education For All, (2012). Civil Society Advocacy Paper for the Second Decade for Education in Africa (2006-15).

Ahikire, J \& Madanda, A. (2011). A survey on re-entry of pregnant girls in primary and secondary schools in Uganda. FAWE Uganda

Alcott, B. Rose, P. \& Sabates, R. (2016) 'Targeted Multidimensional Approaches to Overcome Inequalities in Secondary Education: Case Study of Camfed in Tanzania,' Background Paper, The Learning Generation, The Education Commission

Alecke, B., Burgard,C., Mitze, T. (2013). The Effect of Tuition Fees on Student Enrollment and Location Choice - Interregional Migration, Border Effects and Gender Differences. Ruhr Economic Paper No. 404

Anikina, E., Ivankina, L., Tumanova, I. (2015). Human well-being and educational investment efficiency. International Conference on Research Paradigms Transformation in Social Sciences 2014; Procedia - Social 
and Behavioral Sciences $166,48-52$

Asankha, P \& Takashi, P. (2014). Impacts of Universal Secondary Education Policy on Secondary School Enrollments in Uganda. National Graduate Institute for Policy Studies (GRIPS), Tokyo, Japan.

Asankha, P., Takashi, Y., (2011). "Impacts of Universal Secondary Education policy on secondary school enrolments in Uganda", Journal of Accounting, Finance and Economics, 1(1), 16-30.

Baghdady, A \& Zaki, O. (2019). Secondary Education Governance in Sub-Saharan Africa. World Innovation Summit for Education, Qatar.

Bakwai, B. (2013). Assessment of the role of school community relationship in the development of secondary education in Zamfara State. Sokoto Educational Review Journal, 14(1): 3543.

Barrera-Osorio, F., de Galbert, P., Habyarimana, J., \& Sabarwal, S. (2015). The Impact of Public-Private Partnerships on Private School Performance: Evidence from a Randomized Controlled Trial in Uganda. Policy Research Working Paper; No. 7905. World Bank, Washington, DC.

Barungi, M., (2017) "Does government have to abandon aiding private USE schools?" Commentary,Daily Monitor 31 August, 2017.

Bashir S., Lockheed M., Ninan Dulvy E., Tan J.P. (2017). Facing Forward: Schooling with Learning in Africa. World Bank, Washington DC.

Bo-Joe, B. (2011). Public Private Partnerships in Education: Analyzing PPPs as a policy tool for Universal Secondary Education in Uganda. Universiteit van Amsterdam

Chapman, D., Burton, L., Werner, J. (2010). Universal secondary education in Uganda: the head teachers' dilemma, International Journal of Educational Development, 30(1), 77-82.

Crawfurd, L. (2016). School Management and Public-Private Partnerships. Center for Global Development \& University of Sussex.

Damon, A., Glewwe, P., Wisniewski, S. \&Sun, B (2016). Education in developing countries - what policies and programmes affect learning and time in school? Elanders Sverige AB Stockholm.

Day Ashley L, Mcloughlin C, Aslam M, Engel J, Wales J, Rawal S, Batley R, Kingdon G,Nicolai S, Rose P (2014) The role and impact of private schools in developing countries: a rigorous review of the evidence. Final report. Education Rigorous Literature Review. Department for International Development.

Dejaeghere, J.G., Williams, R., Kyeyune, R., Ugandan secondary school head teachers' efficacy: What kind of training for whom? International Journal of Educational Development, 29, 312-320.

Directorate Education Standards (2014). Enhancing the quality of school management, teaching and Learning processes in education institutions: challenges, best practices and proposed interventions. Education and Sports Sector Review, Kampala, author.

Education Task Force of innovative financing to fund development leading group (2012). Innovative financing for Education: Moving Forward. International Expert Report. Paris, France.

Education and Sports Sector (2016). Annual Performance Report, FY16-17, pp. 200 - 201. Uganda.

Education System: A Review of the Progress, Challenges and Potential Solutions. The Abdul Latif Poverty Action Lab at MIT (J-PAL) and Innovations for Poverty Action (IPA).

Eubanks, D., Eubanks, L.T. (2011). Quality of human resources: Education. The Importance of Secondary Education, Vol 2.

Encyclopedia Britannica (2019). Secondary education. Standard Edition. Chicago:

Gabriela, S.M. (2013). The role of international organizations in the global economic governance - an assessment. Romanian Economic and Business Review - Special issue, 308-316

Glennerster, R., Kremer, M., Mbiti, I. \& Takvarasha, K. (2011). Access and Quality in the Kenya. Nairobi.

Gongera, E \& Okoth, N.O. (2013).Alternative sources of financing secondary schools in rural Kenya: A case of Kisii County, Kenya. Journal of Education and Practice, 4 (4) 104-108

Gogo, J.G.O. (2012). A study on cost effective measures to reduce operational costs of secondary education, a case study of Nyando District. Daystar University Centre for Research, Publications and Consultancy. Working Paper Series, Number DU/2012/003.

Gordon, R. \& Rose, P. (2018). Targeting scholarships and cash transfers for secondary education in Sub-Saharan Africa. Research for Equitable Access and Learning (REAL) Centre, University of Cambridge

Hedger, E., Williamson, T. Muzoora, T. \& Stroh, J. (2010). Sector Budget Support in Practice Case Study Education Sector in Uganda. Overseas Development Institute, UK.

Huylebroeck, L. \& Kristof, T. (2015)'Universal Secondary Education (USE) in Uganda: blessing or curse? The impact of USE on educational attainment and performance'. In: Reyntjens, F., Vandeginste, S. and M. Verpoorten (eds.) L'Afrique des Grands Lacs: Annuaire 2014-2015. Antwerp: University Press Antwerp, 349-372.

Jacob, W. J. \& Lehner, S. (2012). EQUIP2 State-of-the-Art Knowledge in Education; Secondary Education: A Guide to Education Project Design Based on a Comprehensive Literature and Project Review. EQUIP2 State-of-the-Art Knowledge Series. 
JICA \& IDCJ (2012). Education Sector Analysis Report-Uganda. JICA

Jones, S. (2011). Girls' secondary education in Uganda: assessing policy within the women's empowerment framework. Gender and education, 23(4), 385-413

Kazuya, M. \& Chikako, Y. (2016). The Effects of Universal Fee-Free Secondary Education Program on Students' Access, Composition, and Achievement: Evidence from Uganda. Hitotsubashi University.

Kiage J.M, Simatwa E.M.W, Ayodo T.M.O. (2014). Effect of school fees and levies on enrollment of girls in Boarding Public Secondary Schools in Transmara Sub County, Kenya: an analytical study. Educ.Res. 5(5):152-165

Kulild, V. (2014). Role of education in ending extreme poverty -Taking a global lead. Carita seminar on the United Nations Sustainable Development Goals and Post-2015 Development Agenda, Oslo Norway.

Makaaru, A. J., Cunningham, K., Kisaame, K.E., Nansozi, S.M \& Bogere, G. (2015). Public Expenditure Governance in Uganda's Education Sector; Application of an Innovative Assessment Framework. ACODE Policy Research Series No.67, 2015

Matsiko G. M, (2017). Embracing Public Partnerships to Improve Learning Outcomes in Education. CEPA Policy Series Papers NO.15 of 2017. Kampala

Ministry of Education and Sports, (2013). Teacher issues in Uganda: a diagnosis for a shared vision on issues and the designing of a feasible, indigenous and effective teachers' policy. Author Kampala

Ministry of Finance, Planning and Economic Development (2018). Provision of Inclusive Education in Uganda: What are the challenges? BMAU briefing paper (13/18), Kampala, Author

Ministry Of Education and Sports (2016). Education Abstract 2016. Kampala, Education Planning and Policy Analysis Department.

Ministry of gender labour and social development (2011). Resource Mobilization Strategy for Implementation of the National Response to Vulnerable Children. Kampala, Author

Ministry Of Education and Sports, (2013). A Comprehensive Report on Universal Post Primary Education \& Training (UPPET/USE) \& Universal Post O-Level Education \& Training (UPOLET) National Headcount Exercise. Education Planning and Policy Analysis Department, Kampala.

MoES (2016). Education and sports sector strategic plan 2017/18 - 2019/20. Author, Kampala.

Mugendawala, H. (2012). Inequity in educational attainment in Uganda: implications for government policy. International Journal of Global Education. 1(1), 93-101

Namusobya, S., Aubry, S., McKernan, L. (2015). Privatization, Discrimination and the Right to Education in Uganda. Global Initiative for Social and Economic Rights.

National Curriculum Development Centre (2018). Secondary Curriculum. https://www.ncdc.go.ug/

Nunnenkamp, P \& Öhler, H (2010). Funding, Competition and the Efficiency of NGOs: An Empirical Analysis of Non-charitable Expenditure of US NGOs Engaged in Foreign Aid. Kiel Institute for the World Economy, Working Paper No.1640. Hindenburgufer 66, 24105 Kiel, Germany.

Obadara, O \& Alaka, A (2010) "Influence of Resources Allocation in Education on Secondary School Students' Outcome in Nigeria.," Academic Leadership: The Online Journal, 8(4), Article 38.

OECD (2012), Equity and Quality in Education: Supporting Disadvantaged Students and Schools, OECD Publishing. http://dx.doi.org/10.1787/9789264130852-en

Omoeva, C. and Gale, C., (2016). Universal, but not free: Household schooling costs and equityeffects of Uganda's Universal Secondary Education policy. International Journal of Educational Development, 50, pp.41-50.

Omukoba, H.O, Simatwa, E.M.\& Ayodo, T.M. (2011). Contribution of income generating activities to financing secondary school education in Kenya: A case study of Eldoret municipality. Education Research, 2(2), 884897.

Patrinos, H.A. (2016). Why education matters for economic development. Education for Global development. World Bank Group

Revealed through National Education Accounts. UNESCO Institute for Statistics, Montreal.http://uis.unesco.org/sites/default/files/documents/who-pays-for-what-in-educationnationalrevealed-through-accounts-2016-en_0.pdf

Right to Education Project (2012). The right to education Country Fact Sheet; Uganda: saving the future generation. www.right-to-education.org/sites/right-to-education.org/files/resourceattachments/RTE_Country_Factsheet_Uganda_2012.pdf

The Education (pre-primary, primary and post-primary) Act, (2008). Acts Supplement No.8, The Uganda Gazette, 91(44), 13.

Sa'ad, T.U \& Sadiq, A.M. (2014). The Relevance of School Community Relationship on theDevelopment of Primary Education in Azare Metropolis of Bauchi State, Nigeria. OSR Journal of Research \& Method in Education (IOSR-JRME). 4(6), 23-29

Sentongo, J. (2018). The Efficiency of Secondary Education in Sub-Saharan Africa: EESSA Project; The Case 
of Uganda. Mastercard Foundation report, Secondary Education in Africa: Preparing Youth for the Future of Work.

Smith, W. C. \& Baker, T. (2017). From free to fee: Are for-profit, fee-charging private schools The solution for the world's poor? RESULTS Educational Fund.

Trading Economics (2019). Uganda - Government expenditure on secondary education as \% of GDP. https://tradingeconomics.com/uganda/government-expenditure-on-secondary-education-as-\%-of-gdp-\%wb-data.html

Uganda secondary education improvement project (2018). Social assessment report. Kampala, Author

Uganda technology and Management University (2016). Curriculum review report on a framework for the harmonization of lower secondary teacher education curriculum with the revised lower secondary school curriculum, assessment and examination reform in Uganda. UTAM, Kampala.

Uganda Investment Authority (2010). Education Sector Profile. Uganda Investment Authority.

Uganda Bureau of Statistics and ICF (2017), Uganda Demographic and Health Survey, 2016: Key Indicators Report. Kampala, UBOS and Rockville, Maryland, USA: UBOS and ICF.

Uganda National Commission for UNESCO, (2010). Uganda: education for sustainable development implementation strategy. Kampala, Author

UNHCR (2019). Uganda country refugee response plan. The integrated response plan for refugees from South Sudan, Burundi and the Democratic Republic of the Congo. UNHCR

UNESCO (2014), Teacher Issues in Uganda: A shared vision for an effective teachers' policy. UNESCO

UNESCO. (2010). Sustainable development begins with education: how education can contribute to the proposed post-2015 goals. UNESCO Digital Library

UNESCO. (2010). Out-of-School Adolescents. Montreal, Quebec: UNESCO Institute for

Statistics.

UNESCO Institute of Statistics (2018). Education Response Plan for Refugees and Host Communities in Uganda. UNESCO

UNESCO (2014) Teacher Issues in Uganda: A shared vision for an effective teachers' policy. UNESCO.

UNESCO-UIS (2011). Financing Education in Sub-Saharan Africa. Meeting the Challenge of Expansion, Equity and Quality. UNESCO/UIS, Montreal.

UNESCO-IIEP, Pole de Dakar, UNESCO-UIS (2016a). Who Pays for What in Education? The Real Costs. UNESCO.

UNESCO-IIEP, Pole de Dakar, UNESCO-UIS (2016b). Methodology of national education accounts. UNESCO Institute for Statistics, Montreal

UNESCO (2014). Sub-Saharan Africa 2013 EFA Report. Global Education for All Meeting, Muscat, Sultanat of Oman.

United Nations, (2012). The future we want: Outcome document of the United Nations Conference on Sustainable Development. Rio de Janeiro, Brazil.

United Nations, (2017). From Millennium Development Goals to Sustainable Development Goals:Laying the base for 2030. Viantiane, Lao PDR.

United Nations, (2015). The Millennium Development Goals Report 2015. United Nations, New York

Urwick, J., Kisa, S., (2013). Science teacher shortage and the moonlighting culture: The pathology of the teacher labour market in Uganda, International Journal of Educational Development.

Walakira, E.J., D. Muhangi, S. Munyuwiny, F. Matovu, E. Awich, I. Ddumba Nyanzi, J. Kayiwa, J. Akellot, P. Mubiri, J. Majugo, A. Mutebi, M. Ruiz-Rodriguez, (2016). The State of the Ugandan Child - An Analytical Overview. Kampala/ Washing ton DC: USAI D/QED

World Development Report, (2018). World Development, Author

Wodon, K. (2016), Uganda Note: Brief Summary for a first set of notes

World Bank, (2018), Uganda job diagnostics/strategy draft. World Bank

World Bank, (2018a), Uganda job diagnostics/strategy draft.

World Bank (2018b). Uganda Secondary Education Expansion Project (P166570): Project Information Document/ Integrated Safeguards Data Sheet (PID/ISDS). Report No: PIDISDSC24831. World Bank .

Zebun, N.K. (2016). Role of Education in Building Social Cohesion. International Journal of Secondary Education. 4(2) 23-26

Zheng, P \& Libertus, M. (20180. The Role of Parental Education, Household Income, and Race on Parents' Academic Beliefs and the Provision of Home Learning Opportunities for 4- to 8-Year-Old Children. Journal of Educational and Developmental Psychology; 8(1), 118-132. 